Nurjanah, S. • A. Nuraini

\title{
Pengaruh Benzyl Amino Purine dan coumarin terhadap pertumbuhan dan hasil benih kentang (Solanum tuberosum $\mathrm{L}_{\text {.) }} \mathrm{G}_{2}$ kultivar granola
}

\section{The effect of Benzyl Amino Purine and coumarine on growth and yield of potato $\mathrm{G}_{2}$ seed size (Solanum tuberosum $\mathrm{L}$.) cultivar granola}

\author{
Diterima : 15 Februari 2016/Disetujui : 1 Maret 2016 / Dipublikasikan : Maret 2016 \\ CDepartment of Crop Science, Padjadjaran University
}

\begin{abstract}
This experiment started in March until June 2014 and located at Screen House Field of Faculty of Agriculture, Universitas Padjadjaran Jatinangor Campus with altitude $\pm 853 \mathrm{~m}$ above the sea level. The experimental design were used Randomized Block Design with sixteen treatment and three replication. BAP concentration is 0 ppm, 25 ppm, 50 ppm, 75 ppm and coumarine concentration is $0 \mathrm{ppm}, 100 \mathrm{ppm}, 125 \mathrm{ppm}, 150$ $\mathrm{ppm}$. The result of experiment showed that BAP and coumarine concentration gave various effects on plant height, number of leaves, chlorophyll content, number of node, dry weight, number of tuber per plant and number of tuber class SS, but it gave the same effect on percentage stolon forming tuber, weight tuber per plant and number of tuber class $\mathrm{S}, \mathrm{M}$ and $\mathrm{L}$. Giving concentration of BAP without coumarin (25 ppm: 0 ppm) able to increase on plant height. However, giving BAP with a higher concentration of Coumarine (25 ppm: 150 ppm) resulted in more number of tuber when compared to the concentration of BAP without coumarin (75 ppm: 0 ppm).
\end{abstract}

Keywords : Potato $G_{2}$ seed size $\cdot$ Benzyl Amino Purine - Coumarine

Sari Percobaan ini dilakukan dari bulan Maret hingga Juni 2014 di Rumah Plastik Kebun Percobaan Fakultas Pertanian Universitas Padjadjaran Kampus Jatinangor, dengan keting-gian tempat $\pm 853 \mathrm{~m}$ dpl. Rancangan percobaan yang digunakan adalah Rancangan Acak Kelompok (RAK) sederhana yang terdiri dari 16 perlakuan

\footnotetext{
Dikomunikasikan oleh Agus Wahyudin

Nurjanah, S. ${ }^{1} \cdot$ A. Nuraini ${ }^{2}$

${ }^{1}$ Alumni Program Sarjana Agroteknologi UNPAD

2Staf Pengajar di Departemen Budidaya Pertanian

Universitas Padjadjaran

Korespondensi; sitiinurjanah@gmail.com
}

kombinasi BAP dan Coumarin diulang sebanyak 3 kali. Konsentrasi BAP yang digunakan yaitu 0 ppm, 25 ppm, 50 ppm, 75 ppm dan konsentrasi coumarin yang digunakan yaitu $0 \mathrm{ppm}, 100$ ppm, 125 ppm, 150 ppm. Hasil percobaan menunjukkan bahwa pemberian konsentrasi BAP dan coumarin memberikan pengaruh nyata terhadap tinggi tanaman, jumlah daun, kandungan klorofil, jumlah buku, bobot kering tanaman, jumlah ubi per tanaman dan jumlah ubi kelas SS, namun tidak berpengaruh nyata terhadap persentase stolon yang membentuk ubi, bobot ubi per tanaman dan jumlah ubi kelas $\mathrm{S}, \mathrm{M}$ dan L. Pemberian konsentrasi BAP tanpa coumarin (25 ppm : 0 ppm) mampu meningkatkan tinggi tanaman. Akan tetapi pemberian BAP dengan konsentrasi coumarin yang lebih tinggi (25 ppm : 150 ppm) menghasilkan jumlah ubi lebih banyak bila dibandingkan dengan konsentrasi BAP tanpa coumarin (75 ppm : 0 ppm).

Kata kunci : Benih kentang G2 · Benzyl Amino Purine $\cdot$ Coumarin

\section{Pendahuluan}

Kentang (Solanum tuberosum L.) merupakan salah satu komoditas ubi yang memiliki nilai ekonomis tinggi. Komoditas kentang juga merupakan salah satu dari lima komoditas unggulan sayuran semusim (BPS, 2012). Kentang merupakan penghasil kalori tinggi dengan kandungan protein, lemak, dan karbohidrat tinggi (Soewito, 1991). Setiap $100 \mathrm{~g}$ kentang mengandung kalori 347 kkal., dengan kandungan protein $0.3 \mathrm{~g}$, lemak $0.1 \mathrm{~g}$, karbohidrat $85.6 \mathrm{~g}$, kalsium $20 \mathrm{mg}$, fosfor $30 \mathrm{mg}$, zat besi $0.5 \mathrm{mg}$, dan vitamin B $0.04 \mathrm{mg}$ (Samadi, 2007). 
Konsumsi kentang sebagai bahan pangan berkembang cukup cepat, terutama di Asia, walaupun masih lebih kecil dari $20 \mathrm{~kg} /$ kapita/tahun. Bersamaan dengan peningkatan pendapatan per kapita, konsumen cenderung melakukan diversifikasi menu makanan dari dominasi serealia bergeser ke komposisi pangan yang mengandung lebih banyak sayuran, salah satunya adalah kentang (Pusat Data dan Sistem Informasi Pertanian, 2013).

Seiring dengan meningkatnya konsumsi kentang di Indonesia, mendorong produsen kentang untuk dapat meningkatkan produksi kentang. Hal tersebut terlihat pada peningkatan kebutuhan benih kentang yang tidak selaras dengan ketersediaan benih bermutu, pada tahun 2011 produksi benih hanya 15.537 ton sedangkan kebutuhannya 103.582 ton (Rosalina 2011).

Produksi kentang di Indonesia masih sangat rendah jika dibandingkan dengan produksi kentang di Eropa yang rata-ratanya mencapai 25,5 ton per hektar, sedangkan rata-rata di Indonesia hanya sekitar 16 ton per hektar (Pusat Data dan Sistem Informasi Pertanian, 2013). Wattimena (1995) menyatakan terdapat tiga faktor yang menyebabkan rendahnya produksi kentang di Indonesia antara lain; keadaan iklim, teknik budidaya dan faktor pembibitan. Pembibitan tanaman kentang yang baik dipengaruhi oleh benih yang digunakan. Benih baik dan bermutu akan meningkatkan produktivitas dan kualitas produk usaha tani (Satria, 2004).

Salah satu upaya dalam meningkatkan pertumbuhan dan hasil benih kentang adalah dengan mengaplikasikan Zat Pengatur Tumbuh (ZPT) dalam proses budidayanya. Hendaryono dan Wijayani (1994) mengatakan bahwa zat pengatur tumbuh dalam tanaman terdiri dari lima kelompok yaitu auksin, giberellin, sitokinin, etilen dan inhibitor dengan ciri khas dan pengaruh yang berlainan terhadap proses fisiologis.

Sitokinin merupakan salah satu zat pengatur tumbuh yang mempunyai peran dalam proses pembelahan sel (Abidin, 1990) digunakan untuk merangsang terbentuknya tunas, berpengaruh dalam metabolisme sel, dan merangsang sel dorman serta aktivitas utamanya adalah mendorong pembelahan sel. Salah satu jenis sitokinin adalah BAP (Benzyl Amino Purine).

Penambahan zat penghambat tumbuh (Retardan) setelah pemberian BAP dapat dilakukan sebagai salah satu upaya dalam meningkatkan pertumbuhan dan hasil benih kentang $\mathrm{G}_{2}$. Retardan dapat mempengaruhi sifat fisiologis tanaman. Penggunaan taraf konsentrasi retardan yang tepat pada jenis tanaman tertentu akan menghasilkan pertumbuhan dan perkembangan tanaman yang baik. Retardan diperlukan untuk menekan aktivitas giberellin. Hal tersebut dilakukan untuk mempercepat fase generatif sehingga pembentukan ubi meningkat. Salah satu jenis retardan adalah Coumarin yang merupakan salah satu jenis zat penghambat tumbuh. Menurut Wattimena (1988), coumarin merupakan senyawa fenolik yang dapat menghambat kerja giberellin.

Percobaan ini bertujuan untuk untuk mendapatkan konsentrasi zat pengatur tumbuh BAP dan Coumarin yang terbaik terhadap pertumbuhan dan hasil benih kentang $G_{2}$ Kultivar Granola.

\section{Bahan dan Metode}

Penelitian ini dilaksanakan di Kebun Percobaan Fakultas Pertanian Unpad pada bulan MaretJuni 2014. Bahan-bahan yang digunakan yaitu benih kentang $G_{1}$ Kultivar Granola, Benzyl Amino Purine dan Coumarin murni. Media tanam yang digunakan yaitu campuran antara arang sekam, cocopeat dan pupuk kompos dengan perbandingan 2:1:1. Bahan lain yang digunakan yaitu polybag berukuran $40 \times 40 \mathrm{~cm}$, aquades, pupuk NPK, fungisida Dithane M-45 dan insektisida Demolish 18 EC. Alat yang digunakan yaitu ajir/turus, arit, cangkul, selang, timbangan analitik, tali, Klorofilmeter, Termohygrometer, handsprayer, gelas ukur, labu takar, jerigen, oven, drum, seed bed, penggaris, meteran, pelabelan, tali rafia, alat tulis dan kamera.

Percobaan dilakukan dengan mengguna-kan metode Rancangan Acak Kelompok (RAK) sederhana yang terdiri dari 16 perlakuan yang diulang sebanyak 3 kali, yaitu A, Tanpa perlakuan (kontrol); B, BAP : Coumarin (0 ppm : 100 ppm); C, BAP : Coumarin (0 ppm : 125 ppm); D, BAP : Coumarin (0 ppm : 150 ppm); E, BAP : Coumarin (25 ppm : 0 ppm); F, BAP : Coumarin (25 ppm : 100 ppm); G, BAP : Coumarin (25 ppm : 125 ppm); H, BAP : Coumarin (25 ppm : 150 ppm); I, BAP : Coumarin (50 ppm : 0 ppm); J, BAP : Coumarin (50 ppm : 100 ppm); K, BAP : Coumarin (50 ppm : 125 ppm); L, BAP : Coumarin (50 ppm : 150 ppm); M, BAP : Coumarin (75 ppm : 0 ppm); N, BAP : Coumarin (75 ppm : 100 ppm); O, BAP : Coumarin (75 ppm : 125 ppm); P, BAP : Coumarin (75 ppm : $150 \mathrm{ppm})$. 


\section{Hasil dan Pembahasan}

Tinggi Tanaman. Berdasarkan Tabel 1, pemberian BAP dan Coumarin berpengaruh terhadap pertumbuhan tinggi tanaman kentang.

Umur 49 HST dan 63 HST konsentrasi BAP: Coumarin (25 ppm : 0 ppm) (E) dan BAP : Coumarin (50 ppm : $0 \mathrm{ppm}$ ) (I) menghasilkan tinggi tanaman yang lebih tinggi daripada perlakuan BAP : Coumarin (25 ppm : $150 \mathrm{ppm}$ ) (H). Hal ini menunjukkan bahwa pengaruh BAP tanpa coumarin mampu meningkatkan tinggi tanaman kentang karena tidak ada yang menekan pertumbuhan tanaman sehingga pada perlakuan tersebut mengalami pertambahan tinggi tanaman. Hal tersebut sejalan dengan pernyataan Karjadi dan Buchory (2008) bahwa sitokinin (BAP) merangsang terbentuknya tunas dan berpengaruh dalam metabolisme sel, dan merangsang sel dorman serta aktivitas utamanya adalah mendorong pembelahan sel.

Tabel 1. Pengaruh BAP dan Coumarin terhadap Rata-rata Tinggi Tanaman Kentang 49 HST dan 63 HST.

\begin{tabular}{ccc}
\hline \hline \multirow{2}{*}{ Perlakuan } & \multicolumn{2}{c}{ Tinggi Tanaman $(\mathrm{cm})$} \\
\cline { 2 - 3 } & $49 \mathrm{HST}$ & $63 \mathrm{HST}$ \\
\hline $\mathrm{A}$ & $68,00 \mathrm{ab}$ & $73,11 \mathrm{ab}$ \\
$\mathrm{B}$ & $78,00 \mathrm{ab}$ & $78,78 \mathrm{ab}$ \\
$\mathrm{C}$ & $76,67 \mathrm{ab}$ & $81,44 \mathrm{ab}$ \\
$\mathrm{D}$ & $78,44 \mathrm{ab}$ & $82,55 \mathrm{ab}$ \\
$\mathrm{E}$ & $84,89 \mathrm{a}$ & $85,66 \mathrm{a}$ \\
$\mathrm{F}$ & $74,33 \mathrm{ab}$ & $76,78 \mathrm{ab}$ \\
$\mathrm{G}$ & $80,06 \mathrm{ab}$ & $83,45 \mathrm{ab}$ \\
$\mathrm{H}$ & $62,11 \mathrm{~b}$ & $63,89 \mathrm{~b}$ \\
$\mathrm{I}$ & $81,56 \mathrm{a}$ & $88,89 \mathrm{a}$ \\
$\mathrm{J}$ & $68,33 \mathrm{ab}$ & $71,33 \mathrm{ab}$ \\
$\mathrm{K}$ & $76,33 \mathrm{ab}$ & $80,33 \mathrm{ab}$ \\
$\mathrm{L}$ & $76,56 \mathrm{ab}$ & $81,89 \mathrm{ab}$ \\
$\mathrm{M}$ & $74,11 \mathrm{ab}$ & $81,67 \mathrm{ab}$ \\
$\mathrm{N}$ & $69,67 \mathrm{ab}$ & $71,22 \mathrm{ab}$ \\
$\mathrm{O}$ & $74,33 \mathrm{ab}$ & $78,03 \mathrm{ab}$ \\
$\mathrm{P}$ & $78,58 \mathrm{ab}$ & $79,89 \mathrm{ab}$ \\
\hline \hline
\end{tabular}

Perlakuan BAP : Coumarin (25 ppm : 150 ppm) $(\mathrm{H})$, menunjukkan tinggi tanaman yang berbeda diduga karena BAP dengan penambahan coumarin dengan konsentrasi tinggi dapat menekan laju pertumbuhan tinggi tanaman melalui biosintesis giberelin. Runtunuwu dkk. (2011) menyatakan bahwa tinggi tanaman merupakan hasil dari pembelahan dan pemanjangan sel-sel meristem apikal yang distimulasi oleh zat pengatur tumbuh (growth regulator) giberellin, sehingga kekurangan giberellin akan mengakibatkan pertumbuhan yang kerdil pada tanaman. Hal tersebut sejalan dengan pernyataan Weaver (1972) bahwa coumarin sebagai retardan dapat menghambat proses fisiologis dan biokimia dalam tubuh tumbuhan.

Jumlah Daun, Kandungan Klorofil dan Jumlah Buku. Berdasarkan Tabel 2. Menunjukkan bahwa pemberian konsentrasi BAP dan Coumarin memberikan pengaruh nyata terhadap rata-rata jumlah daun tanaman kentang umur 49 HST, kandungan klorofil tanaman kentang umur 45 HST dan jumlah buku tanaman kentang umur 75 HST.

Tabel 2. Pengaruh BAP dan Coumarin terhadap Rata-rata Jumlah Daun Umur 49 HST, Kandungan Klorofil Umur 45 HST dan Jumlah Buku 75 HST.

\begin{tabular}{|c|c|c|c|}
\hline Perlakuan & $\begin{array}{c}\text { Jumlah Daun } \\
\text { per Tanaman } \\
49 \text { HST } \\
\end{array}$ & $\begin{array}{c}\text { Kandungan } \\
\text { Klorofil (cci) } \\
45 \text { HST } \\
\end{array}$ & $\begin{array}{c}\text { Jumlah } \\
\text { Buku } 75 \\
\text { HST } \\
\end{array}$ \\
\hline A & $86,33 \mathrm{ab}$ & $44,28 \mathrm{ab}$ & $18,33 \mathrm{ab}$ \\
\hline B & $105,89 \mathrm{ab}$ & $43,90 \mathrm{ab}$ & $19,33 \mathrm{ab}$ \\
\hline $\mathrm{C}$ & $84,56 \mathrm{ab}$ & $43,68 \mathrm{ab}$ & $14,67 \mathrm{ab}$ \\
\hline $\mathrm{D}$ & $101,22 \mathrm{ab}$ & $42,43 \mathrm{ab}$ & $18,00 \mathrm{ab}$ \\
\hline $\mathrm{E}$ & $102,33 \mathrm{ab}$ & $42,05 \mathrm{ab}$ & $19,67 \mathrm{ab}$ \\
\hline F & $98,00 \mathrm{ab}$ & $48,14 \mathrm{ab}$ & $18,00 \mathrm{ab}$ \\
\hline G & $112,22 \mathrm{a}$ & $50,05 \mathrm{a}$ & $22,00 \mathrm{a}$ \\
\hline $\mathrm{H}$ & $66,00 \mathrm{~b}$ & $46,76 \mathrm{ab}$ & $18,00 \mathrm{ab}$ \\
\hline I & $89,67 \mathrm{ab}$ & $43,36 \mathrm{ab}$ & $19,00 \mathrm{ab}$ \\
\hline $\mathrm{J}$ & $91,56 \mathrm{ab}$ & $47,25 \mathrm{ab}$ & $13,67 \mathrm{~b}$ \\
\hline K & $98,22 \mathrm{ab}$ & $42,83 \mathrm{ab}$ & $14,00 \mathrm{ab}$ \\
\hline $\mathrm{L}$ & $75,78 \mathrm{ab}$ & $39,72 \mathrm{~b}$ & $13,00 \mathrm{~b}$ \\
\hline M & $90,44 \mathrm{ab}$ & $44,65 \mathrm{ab}$ & $18,00 \mathrm{ab}$ \\
\hline $\mathrm{N}$ & $115,44 \mathrm{a}$ & $51,52 \mathrm{a}$ & $12,33 \mathrm{~b}$ \\
\hline $\mathrm{O}$ & $82,22 \mathrm{ab}$ & $45,41 \mathrm{ab}$ & $18,33 \mathrm{ab}$ \\
\hline $\mathrm{P}$ & $87,67 \mathrm{ab}$ & $43,34 \mathrm{ab}$ & $17,67 \mathrm{ab}$ \\
\hline
\end{tabular}

Umur 49 mst perlakuan BAP : Coumarin (25 ppm : 125 ppm) (G) dan BAP : Coumarin (75 ppm : 100 ppm) (N) menghasilkan jumlah daun yang lebih banyak dibandingkan perlakuan BAP : Coumarin (25 ppm : $150 \mathrm{ppm})(\mathrm{H})$ tetapi tidak berbeda dengan perlakuan lainnya. Hal tersebut diduga karena pengaruh kombinasi konsentrasi BAP dan coumarin dapat meningkatkan jumlah daun sedangkan kombinasi konsentrasi BAP dengan konsentrasi coumarin yang terlalu tinggi dapat menghambat jumlah daun. Konsentrasi coumarin yang terlalu tinggi menghambat proses pertumbuhan tanaman. Coumarin merupakan senyawa fenolik. Prawiranata et al., (1981) dikutip 
Sakya et al. (2003) mengemukakan bahwa pengaruh yang paling umum dari pemberian fenolik adalah menghambat tumbuh seperti pembelahan dan pemanjangan sel dihambat.

Konsentrasi BAP : Coumarin (25 ppm : 125 ppm) (G) dan BAP : Coumarin (75 ppm : 100 ppm) (N) menghasilkan kandungan klorofil yang lebih banyak dibandingkan dengan perlakuan BAP : Coumarin (50 ppm : 150 ppm) (L) tetapi tidak berbeda dengan perlakuan lainnya. Hal tersebut diduga karena pemberian BAP dan coumarin dapat meningkatkan kandungan klorofil. Santoso dan Nursandi (2002) dikutip Karintus (2011) menyatakan bahwa sitokinin berperan dalam menunda senescence daun dengan jalan menghambat penguraian protein. Semakin banyak jumlah daun yang dipertahankan akan meningkatkan aktivitas fotosintesis yang pada akhirnya dapat meningkatkan hasil tanaman kentang. Coumarin sebagai retardan dapat meningkatkan kandungan klorofil yang nantinya akan mempengaruhi pembentukan ubi (Hardiyanti, 2013).

Konsentrasi BAP : Coumarin (25 ppm : 125 ppm) (G) menghasilkan jumlah buku terbanyak dibandingkan dengan perlakuan BAP : Coumarin (50 ppm : 100 ppm) (J) dan BAP : Coumarin (50 ppm : 150 ppm) (L) tetapi tidak berbeda dengan perlakuan lainnya. Hal ini diduga karena coumarin sebagai retardan berpengaruh terhadap pertumbuhan dan metabolisme tanaman pada meristem subapikal yang dapat menghalangi pemanjangan sel, akibatnya perpanjangan buku terhambat (Yasin, 2009). BAP berpengaruh terhadap proses fisiologis tanaman, aktivitas utamanya mendorong pembelahan sel (Wattimena, 1988), namun pada penelitian Satria (2004) pemeberian $3 \mathrm{mg} \mathrm{L}^{-1} \mathrm{BAP}$ secara in vitro mengurangi jumlah buku dan tinggi tanaman kentang karena konsentrasi BAP yang cukup tinggi dapat meningkatkan pertumbuhan akar sehingga mengganggu pertumbuhan tanaman.

Bobot Kering Tanaman Kentang. Berdasarkan Tabel 3. menunjukkan bahwa konsentrasi BAP dan Coumarin berpengaruh nyata terhadap rata-rata bobot kering tanaman kentang. Tabel 3 menunjukkan bahwa konsentrasi BAP : Coumarin (25 ppm : 0 ppm) (E), BAP : Coumarin (75 ppm : 125 ppm) (O), BAP : Coumarin (75 ppm : 150 ppm) (P) menghasilkan bobot kering tanaman kentang lebih tinggi dibandingkan dengan perlakuan BAP : Coumarin (50 ppm : 100 ppm) (J) tetapi tidak berbeda nyata dengan perlakuan lainnya.
Perlakuan BAP : Coumarin (75 ppm : 150 ppm) (P) menghasilkan bobot kering lebih tinggi dibandingkan perlakuan lainnya diduga karena pemberian BAP dan coumarin dapat mengoptimalkan proses dan peristiwa yang terjadi dalam pertumbuhan tanaman. Wilkins (1992) menyatakan bahwa sitokinin mampu memacu pembelahan sel, pembentukan organ, meningkatkan aktivitas wadah penampung hara, memacu perkembangan kloroplas dan sintesis klorofil. Kandungan klorofil yang tinggi akan meningkatkan proses fotosintesis tanaman.

Tabel 3. Pengaruh BAP dan Coumarin terhadap Rata-rata Bobot Kering Tanaman Kentang.

\begin{tabular}{cc}
\hline \hline Perlakuan & Bobot Kering Tanaman $(\mathrm{g})$ \\
\hline $\mathrm{A}$ & $46,73 \mathrm{ab}$ \\
$\mathrm{B}$ & $64,80 \mathrm{ab}$ \\
$\mathrm{C}$ & $37,35 \mathrm{ab}$ \\
$\mathrm{D}$ & $51,38 \mathrm{ab}$ \\
$\mathrm{E}$ & $70,13 \mathrm{a}$ \\
$\mathrm{F}$ & $69,66 \mathrm{ab}$ \\
$\mathrm{G}$ & $90,25 \mathrm{a}$ \\
$\mathrm{H}$ & $39,34 \mathrm{ab}$ \\
$\mathrm{I}$ & $43,63 \mathrm{ab}$ \\
$\mathrm{J}$ & $17,40 \mathrm{~b}$ \\
$\mathrm{~K}$ & $37,18 \mathrm{ab}$ \\
$\mathrm{L}$ & $34,24 \mathrm{ab}$ \\
$\mathrm{M}$ & $31,34 \mathrm{ab}$ \\
$\mathrm{N}$ & $40,18 \mathrm{ab}$ \\
$\mathrm{O}$ & $77,07 \mathrm{a}$ \\
$\mathrm{P}$ & $77,50 \mathrm{a}$ \\
\hline \hline
\end{tabular}

Persentase Stolon Membentuk Ubi, Jumlah Ubi dan Bobot Ubi. Berdasarkan Tabel 4. konsentrasi BAP dan Coumarin tidak memberikan pengaruh yang nyata terhadap persentase stolon yang membentuk ubi dan jumlah ubi, namun tidak berpengaruh nyata terhadap bobot ubi tanaman kentang.

Perlakuan BAP dan Coumarin tidak menunjukkan pengaruh yang nyata. Hal ini diduga karena keseimbangan zat pengatur tumbuh tanaman yang terkandung didalam jaringan tanaman kentang sehingga penambahan zat pengatur tumbuh yang diberikan tidak memberikan pengaruh yang nyata. Hal tersebut sejalan dengan pernyataan Gunawan (1995) dikutip Sakya et al. (2003) yang mengemukakan bahwa kebutuhan zat pengatur tumbuh yang diperlukan oleh suatu jenis tanaman sangat tergantung pada zat pengatur tumbuh dalam jaringan tanaman (endogenous), lingkungan tumbuh dan tingkat perkembangan jaringan, bagian yang diisolasi dan sebagainya. 
Tabel 4. Pengaruh BAP dan Coumarin terhadap Persentase Stolon yang Membentuk Ubi, Jumlah Ubi Per Tanaman dan Bobot Ubi Tanaman Kentang.

\begin{tabular}{cccc}
\hline \hline Perlakuan & $\begin{array}{c}\text { Persentase } \\
\text { Stolon } \\
\text { mementuk } \\
\text { Ubi }(\%)\end{array}$ & $\begin{array}{c}\text { Jumlah Ubi } \\
\text { per } \\
\text { Tanaman } \\
(\text { knol })\end{array}$ & $\begin{array}{c}\text { Bobot Ubi } \\
\text { per } \\
\text { Tanaman } \\
(\mathrm{g})\end{array}$ \\
\hline $\mathrm{A}$ & $35,07 \mathrm{a}$ & $8,44 \mathrm{ab}$ & $137,03 \mathrm{a}$ \\
$\mathrm{B}$ & $23,29 \mathrm{a}$ & $8,11 \mathrm{ab}$ & $180,34 \mathrm{a}$ \\
$\mathrm{C}$ & $45,96 \mathrm{a}$ & $7,56 \mathrm{ab}$ & $131,23 \mathrm{a}$ \\
$\mathrm{D}$ & $33,71 \mathrm{a}$ & $8,44 \mathrm{ab}$ & $188,12 \mathrm{a}$ \\
$\mathrm{E}$ & $34,85 \mathrm{a}$ & $8,33 \mathrm{ab}$ & $159,10 \mathrm{a}$ \\
$\mathrm{F}$ & $28,79 \mathrm{a}$ & $7,22 \mathrm{ab}$ & $154,70 \mathrm{a}$ \\
$\mathrm{G}$ & $26,80 \mathrm{a}$ & $8,00 \mathrm{ab}$ & $163,97 \mathrm{a}$ \\
$\mathrm{H}$ & $46,86 \mathrm{a}$ & $10,44 \mathrm{a}$ & $110,04 \mathrm{a}$ \\
$\mathrm{I}$ & $26,93 \mathrm{a}$ & $9,44 \mathrm{ab}$ & $139,81 \mathrm{a}$ \\
$\mathrm{J}$ & $37,62 \mathrm{a}$ & $7,00 \mathrm{ab}$ & $133,97 \mathrm{a}$ \\
$\mathrm{K}$ & $42,72 \mathrm{a}$ & $7,22 \mathrm{ab}$ & $167,15 \mathrm{a}$ \\
$\mathrm{L}$ & $27,15 \mathrm{a}$ & $9,89 \mathrm{ab}$ & $147,17 \mathrm{a}$ \\
$\mathrm{M}$ & $19,98 \mathrm{a}$ & $6,11 \mathrm{~b}$ & $115,38 \mathrm{a}$ \\
$\mathrm{N}$ & $26,13 \mathrm{a}$ & $7,89 \mathrm{ab}$ & $142,75 \mathrm{a}$ \\
$\mathrm{O}$ & $26,29 \mathrm{a}$ & $9,00 \mathrm{ab}$ & $155,18 \mathrm{a}$ \\
$\mathrm{P}$ & $37,17 \mathrm{a}$ & $10,00 \mathrm{ab}$ & $163,73 \mathrm{a}$ \\
\hline
\end{tabular}

Konsentrasi BAP : Coumarin (25 ppm : 150 ppm) (H) menghasilkan jumlah ubi tanaman kentang yang lebih banyak dibandingkan dengan perlakuan BAP : Coumarin $(75 \mathrm{ppm}: 0$ ppm) (M) tetapi tidak berbeda dengan perlakuan lainnya. Hal ini diduga terjadi karena pengaruh dari pemberian coumarin yang dapat menghambat kerja giberelin sehingga pertumbuhan tanaman kentang terfokus pada pembentukan ubi, sedangkan pada perlakuan BAP tanpa coumarin hanya terfokus pada pertumbuhan vegetatif tanaman yang menyebabkan inisiasi ubi menjadi rendah.

Coumarin sebagai retardan mampu merangsang pengumbian dengan jalan menghambat biosintesis giberelin yang berperan dalam pertumbuhan tanaman. Terhambatnya pertumbuhan tanaman mengakibatkan akumulasi asimilat pada batang dan daun sehingga mampu menginduksi terbentuknya ubi (Warnita, 2008).

Konsentrasi BAP dan coumarin tidak memberikan pengaruh nyata terhadap bobot ubi per tanaman. Hal ini diduga karena kombinasi konsentrasi BAP dan coumarin belum tepat sehingga belum mampu meningkatkan bobot ubi per tanaman. Wattimena (1995) menyatakan bahwa kombinasi yang tepat pada pemberian ZPT mampu menghasilkan bobot ubi yang lebih besar.

Jumlah Ubi per Kelas SS, S, M dan L. Berdasarkan Tabel 5 . menunjukkan bahwa pengaruh konsentrasi BAP dan Coumarin berpengaruh nyata terhadap jumlah ubi per kelas SS $(<20 \mathrm{~g})$ dan tidak berpengaruh nyata terhadap jumlah ubi per kelas S (21-30 g), M (31-60 g) dan L $(>60 \mathrm{~g})$.

Perlakuan BAP : Coumarin $(25: 150)(\mathrm{H})$ menghasilkan jumlah ubi kelas SS lebih banyak dibandingkan perlakuan BAP : Coumarin (50 ppm : $125 \mathrm{ppm})(\mathrm{K})$ dan perlakuan BAP : Coumarin (75 ppm : 0 ppm) (M).

Hal ini diduga karena sifat aktif sitokinin yang mendorong pembelahan dan pembesaran sel serta coumarin sebagai zat penghambat tumbuh lebih efektif dalam melakukan penghambatan ataupun penekanan terhadap aktivitas giberelin. Penghambatan giberelin oleh coumarin akan mempercepat masuknya tanaman ke fase generatif karena energi untuk melakukan proses pertumbuhan cabang, buku dan akar diakumulasikan untuk pembentukan ubi sehingga waktu yang dibutuhkan untuk membentuk ubi relatif lebih cepat (Sakya et al., 2003).

Tabel 5. Pengaruh BAP dan Coumarin terhadap Jumlah Ubi per Kelas SS, S, M dan L.

\begin{tabular}{ccccc}
\hline \multirow{2}{*}{ Perlakuan } & \multicolumn{5}{c}{ Julah Ubi per Kelas } \\
\cline { 2 - 5 } & SS & S & M & $\mathrm{L}$ \\
\hline $\mathrm{A}$ & $4,83 \mathrm{ab}$ & $4,67 \mathrm{a}$ & $0,67 \mathrm{a}$ & $0,17 \mathrm{a}$ \\
$\mathrm{B}$ & $4,00 \mathrm{ab}$ & $4,33 \mathrm{a}$ & $1,25 \mathrm{a}$ & $0,50 \mathrm{a}$ \\
$\mathrm{C}$ & $3,17 \mathrm{ab}$ & $5,33 \mathrm{a}$ & $1,50 \mathrm{a}$ & $0,00 \mathrm{a}$ \\
$\mathrm{D}$ & $3,50 \mathrm{ab}$ & $4,67 \mathrm{a}$ & $1,67 \mathrm{a}$ & $0,17 \mathrm{a}$ \\
$\mathrm{E}$ & $4,33 \mathrm{ab}$ & $3,67 \mathrm{a}$ & $2,00 \mathrm{a}$ & $0,00 \mathrm{a}$ \\
$\mathrm{F}$ & $2,33 \mathrm{~b}$ & $4,33 \mathrm{a}$ & $2,08 \mathrm{a}$ & $0,17 \mathrm{a}$ \\
$\mathrm{G}$ & $4,00 \mathrm{ab}$ & $4,50 \mathrm{a}$ & $2,17 \mathrm{a}$ & $0,00 \mathrm{a}$ \\
$\mathrm{H}$ & $9,50 \mathrm{a}$ & $3,50 \mathrm{a}$ & $1,17 \mathrm{a}$ & $0,00 \mathrm{a}$ \\
$\mathrm{I}$ & $6,17 \mathrm{ab}$ & $5,33 \mathrm{a}$ & $0,67 \mathrm{a}$ & $0,17 \mathrm{a}$ \\
$\mathrm{J}$ & $3,17 \mathrm{ab}$ & $4,00 \mathrm{a}$ & $1,08 \mathrm{a}$ & $0,00 \mathrm{a}$ \\
$\mathrm{K}$ & $2,83 \mathrm{~b}$ & $3,67 \mathrm{a}$ & $2,00 \mathrm{a}$ & $0,33 \mathrm{a}$ \\
$\mathrm{L}$ & $5,83 \mathrm{ab}$ & $5,67 \mathrm{a}$ & $1,92 \mathrm{a}$ & $0,17 \mathrm{a}$ \\
$\mathrm{M}$ & $2,50 \mathrm{~b}$ & $4,33 \mathrm{a}$ & $0,92 \mathrm{a}$ & $0,00 \mathrm{a}$ \\
$\mathrm{N}$ & $5,00 \mathrm{ab}$ & $5,00 \mathrm{a}$ & $0,67 \mathrm{a}$ & $0,00 \mathrm{a}$ \\
$\mathrm{O}$ & $4,50 \mathrm{ab}$ & $5,67 \mathrm{a}$ & $0,58 \mathrm{a}$ & $0,33 \mathrm{a}$ \\
$\mathrm{P}$ & $6,50 \mathrm{ab}$ & $4,50 \mathrm{a}$ & $1,25 \mathrm{a}$ & $0,00 \mathrm{a}$ \\
\hline \hline
\end{tabular}

Pemberian BAP dan Coumarin belum mampu menghasilkan pengaruh yang nyata terhadap jumlah ubi kelas S, M dan L. Hal tersebut diduga karena cara aplikasi yang kurang tepat. Hal tersebut disebabkan oleh kemampuan yang berbeda dari daun, batang dan akar pada spesies untuk mengabsorpsi dan translokasi senyawa kimia, adanya mekanisme penonaktifan dalam beberapa spesies, perbedaan pola aksi retardan dalam tanaman. 


\section{Kesimpulan}

1. Terdapat pengaruh pemberian konsentrasi BAP dan Coumarin terhadap tinggi tanaman, jumlah daun, kandungan klorofil, jumlah buku, bobot kering tanaman, jumlah ubi per tanaman dan jumlah ubi kelas SS, namun tidak berpengaruh nyata terhadap persentase stolon yang membentuk ubi, bobot ubi per tanaman dan jumlah ubi kelas S, M dan L.

2. Pemberian konsentrasi BAP tanpa coumarin (25 ppm : $0 \mathrm{ppm}$ ) mampu meningkatkan tinggi tanaman. Akan tetapi pemberian BAP dengan konsentrasi coumarin yang lebih tinggi (25 ppm : $150 \mathrm{ppm}$ ) menghasilkan jumlah ubi lebih banyak bila dibandingkan dengan konsentrasi BAP tanpa coumarin (75 ppm : 0 ppm).

\section{Ucapan Terima Kasih}

Penelitian ini dibiayai oleh PT. Indofood Sukses Makmur Tbk, melalui program Indofood Riset Nugraha 2014-2015.

\section{Daftar Pustaka}

Abidin. 1990. Dasar-Dasar Pengetahuan Tentang Zat Pengatur Tumbuhan. Bandung. Angkasa

Badan Pusat Statistik. 2012. Luas Panen, Produksi, dan Produktifitas Kentang 20092012. Melalui: http://www.bps.go.id/ Diakses tanggal 23 Desember 2013

Hendaryono dan Wijayani. 1994. Teknik Kultur Jaringan: Pengenalan dan Petunjuk Perbanyakan Secara Vegetatif-Modern. http:// books.google.co.id. Diakses pada 25 Januari 2014

Karintus. 2011. Pengaruh Macam Entres dan Konsentrasi BAP Pada Pertumbuhan Okulasi Karet (Hevea brasiliensis Muell Arg). Skripsi. Fakultas Pertanian. Universitas Sebelas Maret

Karjadi dan Buchory. 2008. Pengaruh Auksin dan Sitokinin terhadap Pertumbuhan dan Perkembangan Jaringan Meristem Kentang
Kultivar Granola. J. Hort. 18(4):380-384

Pusat Data dan Sistem Informasi Pertanian. 2013. Buletin Konsumsi Pangan : Vol 4 (1) Th. 2013. Melalui: http://pusdatin.setjen. deptan.go.id/ Diakses pada tanggal 25 Januari 2014

Rosalina. 2011. Indonesia Kekurangan Benih Kentang Unggul. http://www.tempo.co/read/ news/2011/10/26/090363387/ Diakses pada 13 Februari 2014

Runtunuwu, S. D., Mamarimbing, R., Tumewu, $\mathrm{P}$ dan Sondakh, T. 2011. Konsentrasi Paclobutrazol dan Pertumbuhan Tinggi Bibit Cengkeh (Syzygium aromaticum (L) Merryl \& Perry). Euginia, 17(2) : 135-141.

Sakya, A. T., Ahmad Y., Samanhudi dan Ummul B. 2003. Pengaruh Coumarin dan Aspirin dalam Menginduksi Umbi Mikro Kentang (Solanum tuberosum L.). Agrosains Vol. 5 (1), 2003. Melalui : http://pertanian. uns.ac.id/ Diakses pada 4 Maret 2014

Samadi. 2007. Kentang dan Analisis Usaha Tani. Yogyakarta. Kanisius

Satria, B. 2004. Perbanyakan Vegetatif Klon Kentang Unggul (Solanum tuberosum L.) dengan Pemberian Berbagai Konsentrasi BAP Pada Media MS Melalui Kultur Jaringan. Stigma Vol 12(1). Fakultas Pertanian Universitas Andalas Padang

Soewito M. 1991. Memanfaatkan Lahan-lahan Bercocok Tanaman Kentang. Jakarta: Titik Terang

Warnita. 2008. Modifikasi Media Pengumbian Kentang dengan Beberapa Zat Penghambat Tumbuh. Jerami (1): 50-53

Wattimena, G.A. 1988. Zat pengatur tumbuh tanaman. Pusat Antar Universitas, Institut Pertanian Bogor. Bogor. 145 hal. 1995. In Vitro Microtubers As An Alternative Technology For Potato Production. Dept. of Agronomy, Faculty of Agriculture Bogor Agricultural University (IPB), Bogor Indonesia, Dept of Horticulture Univ. of Wisconsin, Madison, USA.

Weaver, R. J. 1972. Plant Growth Subtances in Agriculture. W. H. Freeman and Co., San Francisco USA. 594 p.

Wilkins, M.B., 1992. Fisiologi Tanaman. Penerjemah Sutedjo M.M dan Kartasapoetra A.G. penerbit Bumi Aksara: Jakarta 